\title{
Segmentasi Citra pada Robot Sepak Bola Beroda Menggunakan Multilayer Neural Network dan Fitur Warna HSV
}

\author{
Alam Ar Raad Stone, Nanik Suciati, dan Dini Adni Navastara \\ Departemen Informatika, Fakultas Teknologi Informasi dan Komunikasi, Institut Teknologi Sepuluh Nopember (ITS) \\ e-mail: dini_navastara@if.its.ac.id
}

\begin{abstract}
Abstrak-Robot sepak bola beroda merupakan robot beroda yang dikembangkan untuk bermain sepak bola secara full autonomous. Robot bertanding secara tim melawan tim lain pada lapangan indoor yang telah disesuaikan ukurannya. Selama pertandingan, tidak diperbolehkan adanya campur tangan manusia. Pada robot, telah di pasang sebuah kamera dengan tujuan untuk menemukan di mana objek penting berada. Salah satu tahapan sebelum mendeteksi objek adalah segmentasi. Segmentasi citra bertujuan untuk memisahkan objek dengan latar belakang atau membagi citra ke dalam beberapa daerah dengan setiap daerah memiliki kemiripan atribut. Salah satu cara untuk melakukan segmentasi citra adalah dengan mengklasifikasikan tiap piksel pada citra sebagai objek tertentu maupun latar belakang. Pada penelitian ini, dilakukan klasifikasi tiap piksel pada ruang warna HSV menjadi 6 kelas. Yaitu: kawan (cyan), lawan (magenta), lapangan (hijau), garis lapangan (putih), bola (orange), dan objek lain (hitam). Proses klasifikasi dilakukan dengan menerapkan model Multilayer Neural Network. Kemudian hasil klasifikasi tersebut digunakan untuk membangun lookup table yang akan digunakan untuk klasifikasi tiap piksel warna secara cepat pada komputer robot. Dari hasil uji coba dan fine tuning terhadap hyperparameter dan arsitektur pada multilayer neural network, didapatkan nilai error rata-rata terkecil yaitu $0.16 \%$. Kemudian dari evaluasi hasil segmentasi, diperoleh error rata-rata sebesar $19.37 \%$.
\end{abstract}

Kata Kunci-Lookup Table, Neural Network, Segmentasi Citra.

\section{PENDAHULUAN}

$\mathrm{R}$ OBOT merupakan alat yang dapat membantu manusia baik dengan kontrol oleh manusia maupun secara otomatis dengan program yang telah ditanamkan dahulu pada robot. Untuk memacu perkembangan keilmuan di bidang robotika, maka banyak sekali kontes yang diadakan di seluruh dunia setiap tahunnya dengan tema yang beraneka ragam. Salah satunya adalah Kontes Robot Sepak Bola Indonesia Beroda (KRSBI beroda). Kontes Robot Sepak Bola Indonesia Beroda ini merupakan salah satu kegiatan yang merupakan bagian dari Kontes Robot Indonesia (KRI) sebagai ajang kompetisi rancang bangun dan rekayasa dalam bidang robotika [1]. Kontes Robot Sepakbola Indonesia Beroda diselenggarakan berdasarkan aturan pada lomba internasional RoboCup Middle Size League (MSL).

Di antara banyak bidang riset pada Robot Sepak Bola Beroda, visi komputer merupakan salah satu yang paling menantang. Hal ini dikarenakan robot menangkap citra yang memiliki karakteristik perpindahan lingkungan yang cepat. Pemain kawan, pemain lawan, dan bola berpindah dengan cepat, dan sering kali tidak dapat diprediksi. Robot diharuskan menangkap citra lingkungan tersebut menggunakan kamera, dan menemukan di mana objek penting berada. Tidak ada waktu untuk menjalankan algoritma yang kompleks. Semuanya harus diperhitungkan dalam waktu singkat, atau hanya akan menjadi sia-sia [2].

Salah satu tahapan sebelum mendeteksi objek adalah segmentasi. Segmentasi citra bertujuan untuk memisahkan objek dengan latar belakang atau membagi citra ke dalam beberapa daerah dengan setiap daerah memiliki kemiripan atribut. Salah satu metode segmentasi citra yang sederhana dan sering digunakan adalah thresholding. Metode thresholding dilakukan dengan cara mengganti nilai piksel dengan nilai baru apabila nilai piksel lama berada di antara nilai konstan tertentu. Metode ini berlaku pada citra dengan skala keabuan [3]. Pada citra berwarna, segmentasi dilakukan dengan cara memisahkan tiap komponen warna pada citra, kemudian dilakukan thresholding secara terpisah, lalu digabungkan kembali menggunakan operator and. Saat ini, ada beberapa representasi warna dalam pemrosesan gambar. RGB, CMYK, dan YIQ merupakan representasi warna hardware-oriented. Sementara itu, HSV merupakan representasi warna user-oriented [4]. Model ruang warna yang sering digunakan di dalam proses thresholding pada citra berwarna adalah ruang warna HSV. Bagaimanapun, terkadang sulit untuk menentukan nilai konstan yang akan digunakan pada proses thresholding.

Cara lain untuk melakukan segmentasi citra adalah dengan mengklasifikasikan tiap piksel pada citra sebagai objek tertentu maupun latar belakang. Dalam penelitian ini, akan dilakukan klasifikasi tiap piksel pada ruang warna HSV menjadi 6 kelas. Yaitu: kawan, lawan, lapangan, garis lapangan, bola, dan objek lain. Proses klasifikasi dilakukan dengan menerapkan model multilayer neural network yang dilatih pada komputer lain menggunakan data yang diambil dari robot sepak bola beroda pada waktu yang beragam. Kemudian hasil klasifikasi tersebut digunakan untuk membangun lookup table yang akan digunakan untuk klasifikasi tiap piksel warna secara cepat pada komputer robot.

\section{METODOLOGI}

\section{A. Pembentukan Model Multilayer Neural Network}

Sistem dimulai dengan menerima citra RGB berukuran 480x640 dari kamera Logitech C922. Pada bagian depan 
kamera ini, dipasang lensa fisheye $235^{\circ}$. Karakter lensa fisheye yang cembung menghasilkan citra yang terdistorsi melengkung. Lensa fisheye digunakan untuk meningkatkan angles of view [5]. Kamera dipasang pada bagian atas robot dengan arah menghadap ke bawah. Contoh citra RGB yang didapatkan dapat dilihat pada Gambar 1.
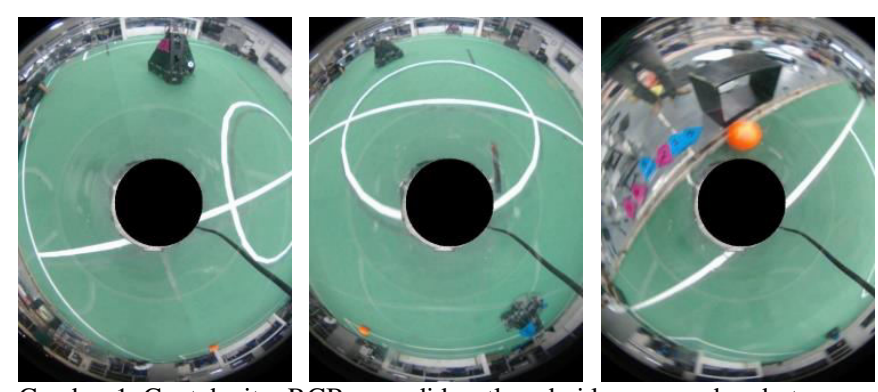

Gambar 1. Contoh citra RGB yang didapatkan dari kamera pada robot.

Kemudian, citra dikonversi ke ruang warna HSV. Persamaan 1-7 dari [6] digunakan untuk konversi citra dari ruang warna RGB ke HSV. Citra yang telah dikonversi, piksel-pikselnya diklasifikasi secara manual ke dalam 6 kelas yang telah ditentukan, yaitu: kawan (cyan), lawan (magenta), lapangan (hijau), garis lapangan (putih), bola (orange), dan objek lain (hitam).

$$
\begin{aligned}
& V \leftarrow \max (R, G, B) \\
& S \leftarrow\left\{\begin{array}{c}
\frac{V-\min (R, G, B)}{v} \begin{array}{c}
\text { if } V \neq 0 \\
\text { otherwise }
\end{array} \\
0 \quad \text { if } V=R
\end{array}\right. \\
& H \leftarrow\left\{\begin{array}{c}
60(G-B) /(V-\min (R, G, B)) \\
120+60(B-R) /(V-\min (R, G, B)) \text { if } V=G \\
240+60(R-G) /(V-\min (R, G, B)) \text { if } V=B
\end{array}\right. \\
& \text { if } H<0, \text { then } H \leftarrow H+360 \\
& V \leftarrow 255 V \\
& S \leftarrow 255 S \\
& H \leftarrow H / 2
\end{aligned}
$$

Karena keterbatasan perangkat keras, tidak dimungkinkan menggunakan seluruh data untuk melatih model multilayer neural network. Sehingga, dari 8.234.496 sampel piksel yang telah terklasifikasi secara manual, dipilih 500.000 data secara random. Dari data terpilih, 80 persennya digunakan sebagai data training, kemudian sisanya sebagai data testing.

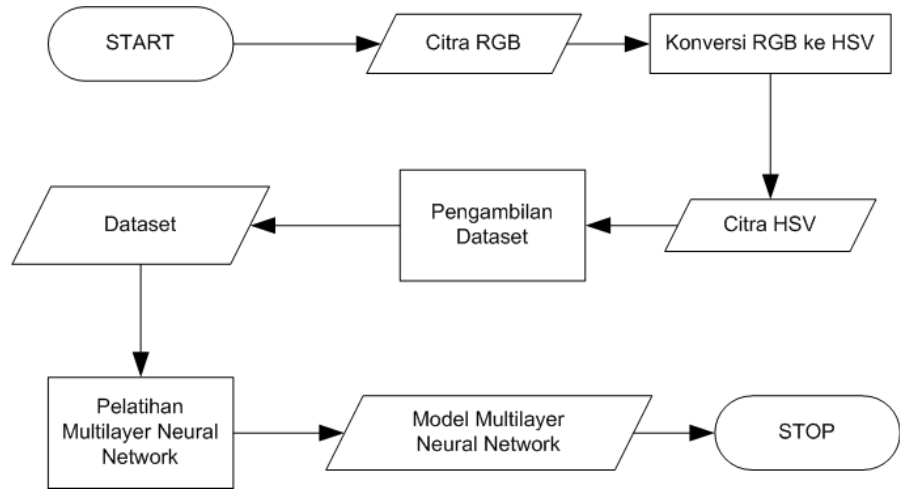

Gambar 2. Flowchart program pembentukan model multilayer neural network.

Dataset yang dihasilkan dari tahap pengambilan dataset ialah piksel-piksel HSV yang telah terklasifikasi secara manual kedalam 6 kelas. Dataset kemudian digunakan pada tahap pelatihan multilayer neural network. Multilayer neural network yang akan dilatih terdiri dari input layer dengan 3 neuron (nilai hue, nilai saturation, dan nilai value), 1 hidden layer dengan jumlah neuron yang akan dilakukan uji coba, dan output layer dengan 6 neuron, serta menggunakan fungsi aktivasi sigmoid. Secara umum, flowchart program pembentukan model multilayer neural network dapat dilihat pada Gambar 2.

\section{B. Pembentukan Lookup Table}

Implementasi sebenarnya pada robot, lookup table digunakan untuk menggantikan operasi perhitungan multilayer neural network dengan operasi indeks. Dengan menggunakan lookup table waktu untuk komputasi secara signifikan dapat lebih cepat karena mendapatkan data dari memori memakan waktu yang relatif singkat dibandingkan dengan melakukan operasi perhitungan. 


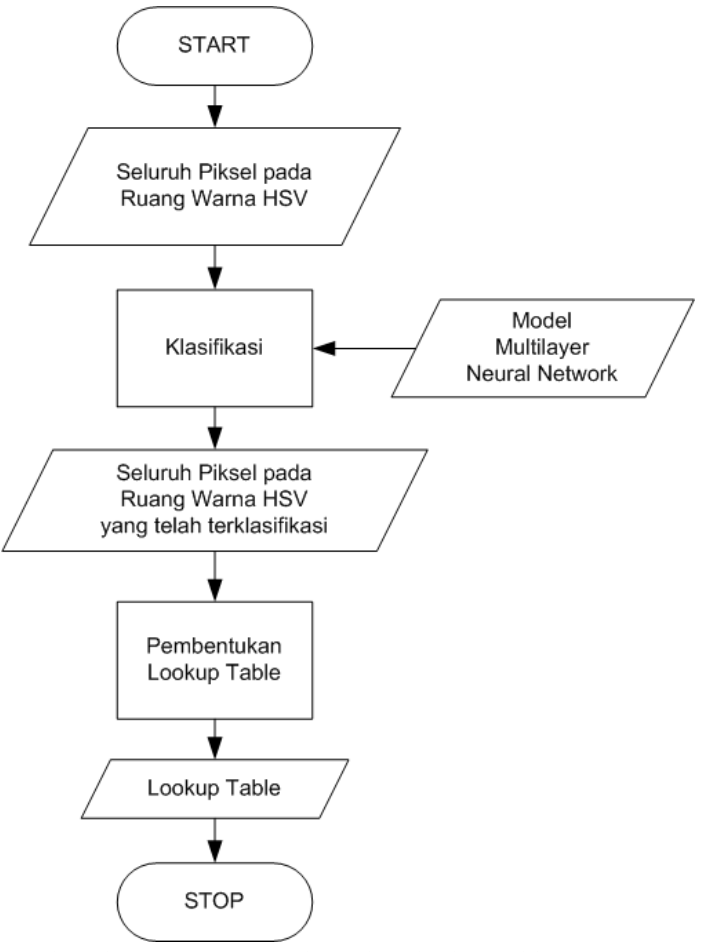

Gambar 3. Flowchart program pembentukan lookup table

Pada tahap ini, model multilayer neural network digunakan untuk mengklasifikasikan seluruh piksel pada ruang warna HSV. Kemudian hasil klasifikasi disimpan pada lookup table. Indeks lookup table merupakan hasil operasi or antara nilai hue (8 bit) yang telah dilakukan shift left sebanyak 16, nilai saturation (8 bit) yang telah dilakukan shift left sebanyak 8 , dan nilai value (8 bit).

Lookup table disimpan pada file untuk digunakan pada komputer robot. File yang dihasilkan berupa binary file berukuran sekitar 16 megabyte. Flowchart program pembentukan lookup table dapat dilihat pada Gambar 3. Ilustrasi lookup table dapat dilihat pada Tabel 1.

Tabel 1.

Ilustrasi lookup table.

\begin{tabular}{llllll}
\hline \hline $\mathrm{H}$ & $\mathrm{S}$ & $\mathrm{V}$ & Indeks (bin) & Indeks (int) & Kelas \\
\hline 0 & 0 & 0 & $\begin{array}{l}000000000000 \\
000000000000\end{array}$ & 0 & 3 \\
& & & & \\
0 & 0 & 1 & 000000000000 & 1 & 3 \\
& & & 000000000001 & & \\
$\ldots$ & $\ldots$ & $\ldots$ & $\ldots$ & $\ldots$ & $\ldots$ \\
0 & 1 & 0 & 000000000000 & 256 & 3 \\
& & & 000100000000 & & \\
0 & 1 & 1 & 000000000000 & 257 & 3 \\
& & & 000100000001 & & $\ldots$ \\
$\ldots$ & $\ldots$ & $\ldots$ & $\ldots$ & $\ldots$ & 5 \\
255 & 255 & 255 & 111111111111 & 16777215 & \\
& & & 11111111111 & & \\
\hline \hline
\end{tabular}

\section{UJI COBA DAN EVALUASI}

\section{A. Lingkungan Uji Coba}

Lingkungan implementasi pada penelitian ini adalah sebuah personal computer (PC). PC yang digunakan pada penelitian ini memiliki prosesor Intel Core i5-7200U dengan kecepatan 2,6 GHz, dan Random Access Memory (RAM) sebesar 4 GB. Program dibangun menggunakan Python 3.6 pada sistem operasi Windows dengan menggunakan IDE PyCharm, serta C++ menggunakan IDE Visual Studio 2015 dengan pustaka pendukung OpenCV.

Spesifikasi tersebut cukup memadai untuk melatih model multilayer neural network dengan kecepatan komputasi yang baik, namun RAM masih cenderung kurang, sehingga tidak semua dataset dapat digunakan, melainkan hanya sebagian kecil saja.

\section{B. Fine Tuning Hyperparameter}

Fine tuning hyperparameter bertujuan untuk mencari konfigurasi hyperparameter yang paling baik pada multilayer neural network pada dataset yang telah diperoleh. Pada penelitian ini akan dilakukan fine tuning pada learning rate dan lambda. Untuk mengurangi fluktuasi pada kualitas model, akan diambil nilai rata-rata dari 2 pengujian pada masingmasing konfigurasi.

\section{Learning Rate}

Hyperparameter yang dilakukan fine tuning pertama kali ialah learning rate. Pada proses fine tuning learning rate, jumlah epoch yang digunakan berjumlah 50, dengan batch size sebanyak 10. Fine tuning pada proses ini tidak menggunakan L2 regularization, sehingga lambda diset dengan nilai 0,0 . Konfigurasi yang digunakan dapat dilihat pada Tabel 2.

Dari hasil pengujian menggunakan berbagai nilai learning rate yang berbeda, didapatkan rata-rata error terkecil pada nilai learning rate 0,3 . Sehingga, selanjutnya proses fine tuning akan dilakukan dengan menggunakan nilai learning rate 0,3 . Hasil dari pengujian learning rate dapat dilihat pada Tabel 3. Dari informasi pada Tabel 2, didapatkan rata-rata error terkecil pada nilai learning rate 0,3. Sehingga, selanjutnya pengujian akan dilakukan dengan menggunakan nilai learning rate 0.3 .

Tabel 2.

Hyperparameter dan arsitektur tetap pengujian learning rate.

\begin{tabular}{|c|c|}
\hline Nama & Nilai \\
\hline \\
\hline \multicolumn{2}{|c|}{$\begin{array}{c}\text { Hyperparameter Jaringan } \\
50\end{array}$} \\
\hline \multicolumn{2}{|l|}{ Batch Size } \\
\hline \multicolumn{2}{|l|}{ Lambda } \\
\hline \multicolumn{2}{|c|}{ Arsitektur Jaringan } \\
\hline Neuron tiap Layer & $3-6-6$ \\
\hline
\end{tabular}

Tabel 3.

Hasil pengujian learning rate.

\begin{tabular}{ccc}
\hline \hline Learning Rate & $\begin{array}{c}\text { Rata-rata } \\
\text { Error Training }\end{array}$ & $\begin{array}{c}\text { Rata-rata } \\
\text { Error Testing }\end{array}$ \\
\hline 0,01 & $0,79 \%$ & $0,77 \%$ \\
0,1 & $0,32 \%$ & $0,33 \%$ \\
0,2 & $0,40 \%$ & $0,42 \%$ \\
0,3 & $0,26 \%$ & $0,25 \%$ \\
0,4 & $0,29 \%$ & $0,28 \%$ \\
\hline \hline
\end{tabular}

Lambda 
Setelah dilakukan proses fine tuning learning rate, proses selanjutnya yaitu fine tuning lambda. Lambda merupakan hyperparameter pada L2 regularization. Pada proses fine tuning lambda, jumlah epoch yang digunakan berjumlah 50, dengan batch size sebanyak 10, serta learning rate 0,3 yang merupakan nilai terbaik yang didapatkan dari proses fine tuning learning rate. Konfigurasi yang digunakan dapat dilihat pada Tabel 4.

Tabel 4.

Hyperparameter dan arsitektur tetap pengujian lambda

\begin{tabular}{lc}
\hline \hline & Nama \\
Epoch & Hyperparameter Jaringan \\
Batch Size & 50 \\
Learning Rate & 10 \\
& 0,3 \\
Neuron tiap Layer & Arsitektur Jaringan \\
\hline \hline
\end{tabular}

Dari hasil pengujian, didapatkan rata-rata error terkecil pada nilai lambda 0,1 . Sehingga, selanjutnya pengujian akan dilakukan dengan menggunakan nilai lambda 0,1 . Hasil dari pengujian lambda dapat dilihat pada Tabel 5.

Tabel 5.

Hasil pengujian lambda.

\begin{tabular}{ccc}
\hline \hline Lambda & $\begin{array}{c}\text { Rata-rata } \\
\text { Error Training }\end{array}$ & $\begin{array}{c}\text { Rata-rata } \\
\text { Error Testing }\end{array}$ \\
\hline 0 & $0,26 \%$ & $0,25 \%$ \\
0,1 & $0,21 \%$ & $0,21 \%$ \\
0,01 & $0,27 \%$ & $0,26 \%$ \\
0,001 & $0,43 \%$ & $0,43 \%$ \\
\hline \hline
\end{tabular}

\section{Perbandingan Arsitektur}

Secara umum, multilayer neural network dapat memiliki hidden layer dan neuron pada tiap layer dengan jumlah berapapun. Namun, pada penelitian ini, arsitektur jaringan yang digunakan dibatasi dengan menggunakan 1 hidden layer saja, dengan jumlah neuron pada input layer berjumlah 3 (nilai hue, nilai saturation, dan nilai value), dan jumlah neuron pada output layer berjumlah 6 (kawan, lawan, lapangan, garis lapangan, bola, dan objek lain), serta menggunakan fungsi aktivasi sigmoid. Sehingga perbandingan arsitektur dilakukan dengan membandingkan jumlah neuron pada hidden layer. Konfigurasi yang digunakan pada pengujian arsitektur merupakan hasil fine tuning yang telah dilakukan sebelumnya, yaitu learning rate dengan nilai 0,3 dan lambda dengan nilai 0,1 . Konfigurasi yang digunakan dapat dilihat pada Tabel 6.

Tabel 6.

Hyperparameter pengujian arsitektur jaringan.

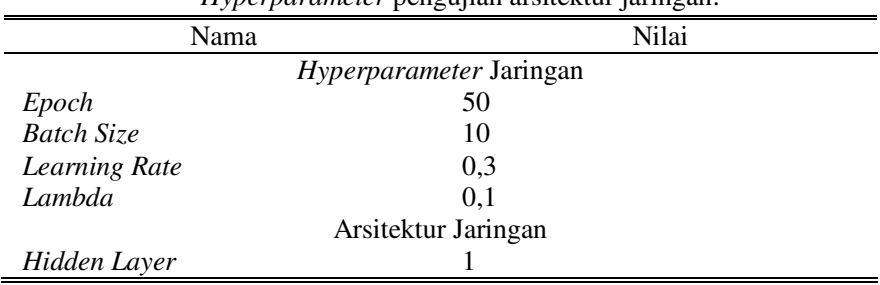

Dari hasil pengujian, didapatkan rata-rata error terkecil sebesar $0,16 \%$ pada arsitektur jaringan dengan 15 neuron pada hidden layer. Berdasarkan hasil pengujian, terlihat bahwa jumlah neuron pada hidden layer berbanding lurus dengan run time, yang berarti bahwa proses komputasi akan semakin lama apabila jumlah neuron semakin banyak. Namun demikian, semakin banyak neuron tidak selalu menghasilkan error yang lebih kecil. Hasil dari pengujian arsitektur multilayer neural network dapat dilihat pada Tabel 7. Dari hasil perbandingan arsitektur ini, arsitektur jaringan multilayer neural network dengan rata-rata error terkecil akan digunakan untuk klasifikasi tiap piksel pada ruang warna HSV yang akan digunakan pada proses selanjutnya.

Tabel 7.

Hasil pengujian arsitektur jaringan.

\begin{tabular}{cccc}
\hline \hline Neuron tiap Layer & Rata-rata Run Time & $\begin{array}{c}\text { Rata-rata } \\
\text { Error Training }\end{array}$ & $\begin{array}{c}\text { Rata-rata } \\
\text { Error Testing }\end{array}$ \\
\hline $3-6-6$ & 51,72 menit & $0,21 \%$ & $0,21 \%$ \\
$3-10-6$ & 56,12 menit & $0,19 \%$ & $0,20 \%$ \\
$3-13-6$ & 55,87 menit & $0,17 \%$ & $0,17 \%$ \\
$3-15-6$ & 57,52 menit & $0,16 \%$ & $0,16 \%$ \\
$3-17-6$ & 61,41 menit & $0,18 \%$ & $0,19 \%$ \\
$3-20-6$ & 55,36 menit & $0,22 \%$ & $0,20 \%$ \\
$3-50-6$ & 53,25 menit & $0,23 \%$ & $0,22 \%$ \\
$3-100-6$ & 65,08 menit & $0,21 \%$ & $0,21 \%$ \\
$3-200-6$ & 68,00 menit & $0,19 \%$ & $0,18 \%$ \\
$3-300-6$ & 73,53 menit & $0,22 \%$ & $0,23 \%$ \\
$3-400-6$ & 77,73 menit & $0,18 \%$ & $0,17 \%$ \\
$3-500-6$ & 90,02 menit & $0,27 \%$ & $0,25 \%$ \\
\hline \hline
\end{tabular}

\section{Uji Coba Segmentasi}

Uji coba segmentasi dilakukan untuk memastikan apakah lookup table yang telah dibuat berdasarkan hasil klasifikasi menggunakan multilayer neural network telah layak diimplementasikan pada robot. Uji coba dilakukan dengan membandingkan tingkat error segmentasi dan waktu pemrosesan antara sistem lama yang telah diimplementasikan pada robot sebelumnya (menggunakan metode thresholding) dan sistem yang digunakan pada penelitian ini.

Tiap piksel citra hasil segmentasi dari kedua sistem akan dibandingkan dengan ground truth. Error dihitung dengan menggunakan Persamaan 8. dengan total data merupakan panjang citra dikalikan dengan lebar citra, dan prediksi salah merupakan jumlah piksel yang tidak sesuai dengan ground truth. Jumlah citra yang digunakan untuk uji coba adalah 4 citra, dengan ground truth merupakan citra uji coba yang telah dilakukan segmentasi secara manual oleh manusia.

error $=\frac{\text { prediksi salah }}{\text { total data }} \times 100 \%$

Metode segmentasi yang digunakan pada penelitian ini ialah dengan melakukan klasifikasi tiap piksel pada citra yang telah dikonversi ke HSV berdasarkan lookup table yang dibangun dari hasil klasifikasi tiap piksel pada ruang warna HSV menggunakan multilayer neural network. Flowchart pengujian hasil segmentasi menggunakan metode ini dapat dilihat pada Gambar 4. 


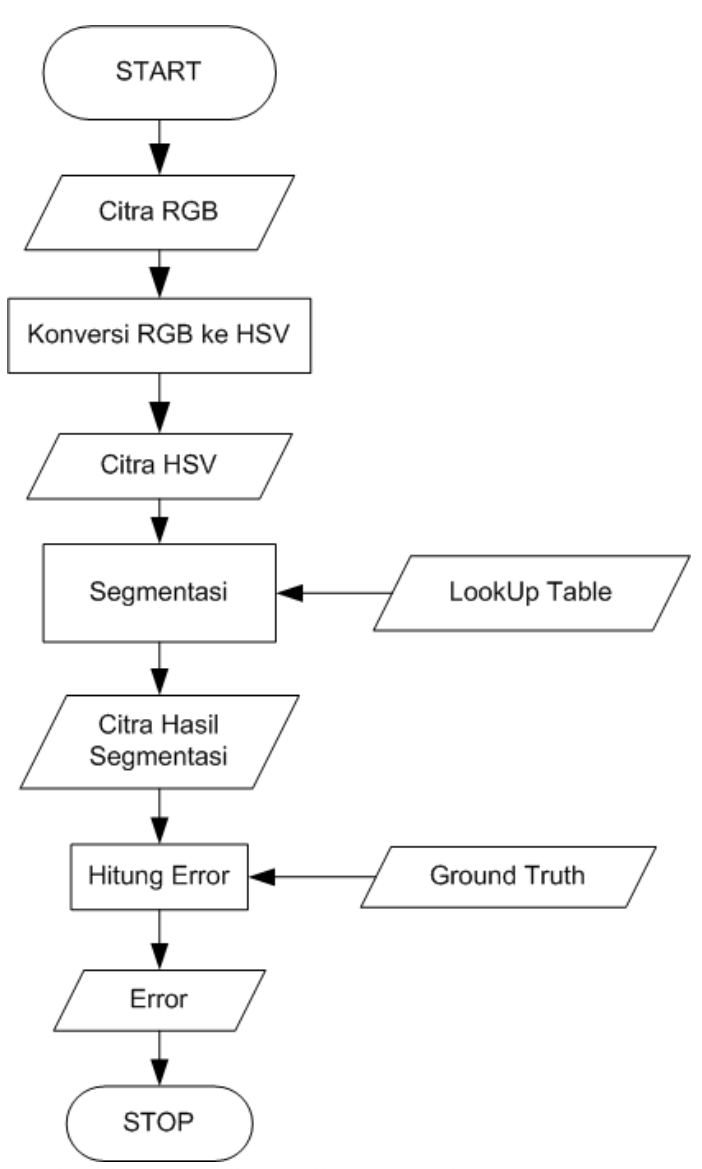

Gambar 4. Flowchart pengujian hasil segmentasi.

Sedangkan, metode thresholding dilakukan dengan cara mengganti nilai piksel dengan nilai baru sesuai dengan kelasnya, apabila nilai piksel lama berada di antara nilai konstan tertentu. Parameter tetap yang digunakan pada sistem lama dengan metode thresholding dapat dilihat pada Tabel 7.

Tabel 8.

Parameter tetap metode thresholding.

\begin{tabular}{ccccccc}
\hline \hline \multirow{2}{*}{ Kelas } & \multicolumn{3}{c}{ Hue } & \multicolumn{2}{c}{ Saturation } & \multicolumn{2}{c}{ Value } \\
\cline { 2 - 7 } & $\min$ & $\max$ & $\min$ & $\max$ & $\min$ & $\max$ \\
\hline Hijau & 37 & 64 & 37 & 121 & 125 & 255 \\
Putih & 0 & 255 & 0 & 50 & 177 & 255 \\
Orange & 60 & 125 & 52 & 255 & 202 & 255 \\
Cyan & 16 & 64 & 196 & 255 & 144 & 255 \\
Magenta & 127 & 148 & 66 & 215 & 121 & 240 \\
Hitam & 0 & 255 & 0 & 255 & 0 & 83 \\
\hline \hline
\end{tabular}

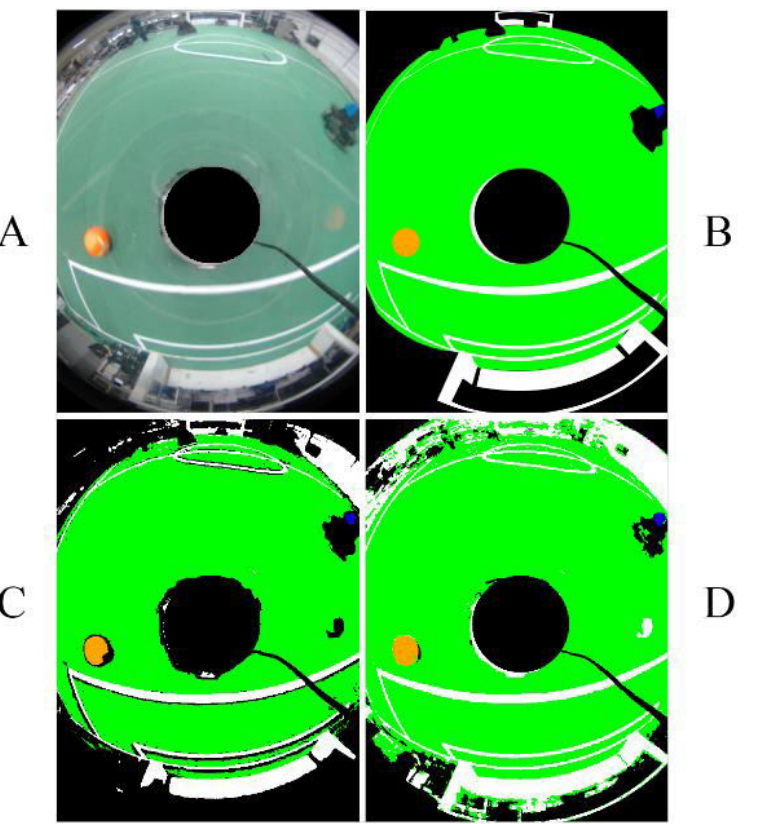

Gambar 5. (A) Citra asli, (B) ground truth, (C) hasil segmentasi menggunakan sistem lama, dan (D) hasil segmentasi menggunakan sistem baru.

Berdasarkan hasil uji coba segmentasi, error rata-rata yang didapatkan pada sistem baru lebih besar daripada sistem lama. Hal ini dikarenakan banyaknya noise yang terdapat pada citra, seperti warna tembok yang mirip dengan garis lapangan. Namun, secara visual, terlihat bahwa hasil segmentasi menggunakan sistem baru memberikan hasil yang lebih baik di dalam lapangan dibandingkan dengan sistem lama. Sedangkan kecepatan segmentasi menggunakan sistem baru lebih cepat daripada sistem lama. Hal ini dikarenakan operasi baca memori memakan waktu yang relatif singkat dibandingkan dengan melakukan operasi perhitungan dan operasi logika. Hasil dari uji coba segmentasi dapat dilihat pada Tabel 8. Sedangkan contoh citra hasil segmentasi dapat dilihat pada Gambar 5.

Tabel 9.

Hasil uji coba segmentasi.

\begin{tabular}{cccc}
\hline \hline Keterangan & Citra ke- & Run Time & Error \\
\hline \multirow{5}{*}{ Sistem Lama } & 1 & $0.1700 \mathrm{~s}$ & $9.55 \%$ \\
& 2 & $0.1660 \mathrm{~s}$ & $12.75 \%$ \\
& 3 & $0.1770 \mathrm{~s}$ & $8.87 \%$ \\
& 4 & $0.1630 \mathrm{~s}$ & $13.18 \%$ \\
& Rata-rata & $0.1690 \mathrm{~s}$ & $11.09 \%$ \\
Sistem Baru & 1 & $0.0620 \mathrm{~s}$ & $14.92 \%$ \\
& 2 & $0.0710 \mathrm{~s}$ & $16.05 \%$ \\
& 3 & $0.0560 \mathrm{~s}$ & $12.96 \%$ \\
& 4 & $0.0550 \mathrm{~s}$ & $33.57 \%$ \\
\hline \hline
\end{tabular}

Sistem lama yang dimaksud pada Tabel 8 merupakan metode segmentasi yang telah diimplementasikan pada robot sebelumnya, yaitu menggunakan thresholding. Sedangkan sistem baru yang dimaksud pada tugas akhir ini ialah metode segmentasi yang akan diimplementasikan pada robot, yaitu menggunakan lookup table yang dibangun dari hasil klasifikasi tiap piksel pada ruang warna HSV menggunakan multilayer neural network. 


\section{KESIMPULAN/RINGKASAN}

Berdasarkan hasil fine tuning hyperparameter, didapatkan error pengujian terkecil pada nilai learning rate sebesar 0,3, dan nilai lambda sebesar 0,1 . Kemudian, dari serangkaian hasil uji coba, didapatkan model akhir dengan nilai error pada data testing sebesar $0,16 \%$, atau mendapat nilai akurasi sebesar $99,84 \%$. Pelatihan dari model tersebut berjalan selama 57,52 menit. Berdasarkan hasil uji coba, selisih nilai error training dan error testing bernilai sangat kecil. Sehingga dapat disimpulkan bahwa tidak terjadi overfitting pada model yang telah dibangun. Berdasarkan uji coba segmentasi, didapatkan error rata-rata sebesar $19,38 \%$ pada sistem baru, lebih besar daripada sistem lama. Hal ini dikarenakan banyaknya noise yang terdapat pada citra, seperti warna tembok yang mirip dengan garis lapangan. Kecepatan segmentasi menggunakan lookup table sedikit lebih cepat daripada thresholding. Hal ini dikarenakan operasi baca memori memakan waktu yang relatif singkat dibandingkan dengan melakukan operasi perhitungan dan operasi logika. Sehingga, segmentasi menggunakan lookup table layak diimplementasikan pada robot yang memiliki visi dengan karakteristik perpindahan lingkungan yang cepat seperti robot sepak bola beroda.

Pembuatan program pelatihan model multilayer neural network pada penelitian ini dilakukan tanpa bantuan pustaka pihak ketiga, sehingga komputasi dilakukan belum menggunakan GPU. Pada penelitian selanjutnya, disarankan untuk menggunakan pustaka pihak ketiga yang mendukung komputasi menggunakan GPU pada tahap pelatihan multilayer neural network, sehingga waktu pelatihan dapat dilakukan dengan lebih cepat. Kemudian, perlu adanya proses dan pengembangan lebih lanjut sehingga hasil segmentasi dapat diolah menjadi data yang berguna bagi robot.

\section{DAFTAR PUSTAKA}

[1] D. J. P. d. K. Direktorat Kemahasiswaan, "Buku Panduan Kontes Robot Sepakbola Indonesia Divisi Beroda," Kementerian Riset, Teknologi dan Pendidikan Tinggi Republik Indonesia, 2018.

[2] A. J. R. Neves, A. J. Pinho, D. A. Martins and B. Cunha, "An Efficient Omnidirectional Vision System For Soccer Robots: From Calibration To Object Detection," Mechatronics, vol. 21, pp. 399-410, 2011.

[3] A. Rachmawan, "Penentuan Posisi Robot Sepak Bola Beroda Menggunakan Rotary Encoder dan Kamera," Fakultas Teknologi Elektro, Institut Teknologi Sepuluh Nopember, Surabaya, 2017.

[4] N. Suciati, D. Herumurti and A. Y. Wijaya, "Fractal-based Texture and HSV Color Features for Fabric Image Retrieval," International Conference on Control System, Computing and Engineering, pp. 178-182, 2015.

[5] Y. Prakoso, "Desain Dan Implementasi Pengukuran Posisi Bola Menggunakan Kamera 360 Derajat Pada Robot Sepak Bola," Fakultas Teknologi Elektro, Institut Teknologi Sepuluh Nopember, Surabaya, 2017.

[6] "OpenCV: Color conversions," [Online]. Available: https://docs.opencv.org/3.4.1/de/d25/imgproc_color_conversions.html\#co lor_convert_rgb_hsv. [Accessed 27 Juni 2018].

[7] D. Svozil, V. Kvasnicka and J. Pospichal, "Introduction to Multi-layer Feed-forward Neural Networks," Chemometrics and Intelligent Laboratory Systems, no. 39, pp. 43-62, 1997.

[8] J. Bruce, T. Balch and M. Veloso, "Fast and Inexpensive Color Image Segmentation for Interactive Robots," in Intelligent Robots and Systems, 2000. (IROS 2000)., Takamatsu, Japan, 2000.

[9] M. A. Morshidi, M. H. Marhaban and A. Jantan, "Color segmentation using multi layer neural network and the HSV color space," in International Conference on Computer and Communication Engineering, 2008. ICCCE 2008, Kuala Lumpur, Malaysia, 2008.

[1 M. A. Nielsen, "Neural Networks and Deep Learning," Determination 0] Press, 2015. 